\title{
Bolesti zad u mladých pacientů z pohledu revmatologa
}

V revmatologickém bloku 16. konference Interní medicína pro praxi zazněla přednáška upozorňující na dlouhou prodlevu (až 9 let) mezi vznikem příznaků ankylozující spondylitidy a stanovením diagnózy tohoto invalidizujícího onemocnění rozvíjejícího se v časné dospělosti. MUDr. Jiří Novosad připomněl současnou možnost diagnostiky pomocí magnetické rezonance a dostupnost biologické léčby. Zdůraznil, že při včasném zahájení léčby lze předejít invalidizaci nemocného. Proto by měl být na vyšetření k revmatologovi odeslán každý pacient mladší 45 let s chronickou bolestí zad, která má zánětlivý charakter (pliživý začátek, horší v klidu, zmírnění při pohybu), nebo s prokázanou sakroileitidou pomocí zobrazovací metody nebo s pozitivitou antigenu HLA B27.

\section{Chronická zánětlivá bolest zad může být př́znakem spondyloartritidy}

Bolest zad může mít různé charakteristiky. Rozlišujeme bolest akutní vs. chronickou, bolest při pohybu vs. v klidu, bolest iradiační vs. lokalizovanou, bolest traumatické etiologie vs. z pracovního přetížení, další charakteristikou může být ranní ztuhlost nebo zhoršení bolesti při nádechu.

Pokud se jedná o bolest chronickou, prítomnou v klidu a spojenou s ranní ztuhlostí, je třeba etiologicky pomýšlet na bolest zánětlivého původu. Chronická bolest je definována délkou trvání přesahující 3 měsíce. Zánětlivá chronická bolest zad mívá plíživý začátek, bolest je prrítomna v noci a v klidu, při rozcvičení se zlepšuje a objevuje se poprvé před 40. rokem věku. Pacienti si typicky stěžují na bolest v druhé polovině noci, která se zmírní při protažení. Tento typ bolesti je suspektní pro spondyloartritidy (SpA). Jde o skupinu zánětlivých revmatických onemocnění se společnými rysy zahrnujícími přítomnost sakroileitidy/ spondylitidy, familiární výskyt a pozitivitu antigenu HLA B27. Někdy se u pacientů vyskytuje také psoriáza, daktylitida, entezitida, oční postižení nebo nespecifické střevní záněty.

Podle převažující manifestace dělíme SpA na axiální a periferní. Z klinických jednotek sem spadá ankylozující spondylitida (AS), psoriatická artritida, reaktivní artritida, enteropatické artritidy, juvenilní idiopatická artritida (s entezitidou), akutní uveitida a nediferencované spondyloartritidy.

\section{Axiální spondyloartritida má časnou neradiologickou a klasickou radiologickou formu}

AS, neboli morbus Bechtěrev; jedná se o chronické zánětlivé onemocnění kloubů páteře. Je charakterizováno osteoproliferativními změnami s tvorbou intervertebrálních přemostění (syndesmofytů) a osifikací paravertebrálních vazů vedoucích k omezení pohyblivosti páteře.

Etiologicky je onemocnění asociováno s prrítomností antigenu HLA B27 a v současné době je diskutován i pravděpodobný vliv environmentálních faktorů, zejména střevního mikrobiomu.

Nově dělíme axiální spondyloartritidy na neradiologickou a radiologickou formu, což umožňuje časnější stanovení diagnózy axiální SpA.
V neradiologickém období, které může trvat zhruba 5-9 let, je přítomna nediferencovaná axiální SpA projevující se zánětlivou bolestí zad. Radiologické období odpovídá klasické ankylozující spondylitidě (AS), kdy je již kromě bolesti zad prítomna sakroileitida v rentgenovém obraze a postupně se rozvíjejí syndesmofyty (1). Ne u všech nemocných dojde k vývoji od neradiografické formy směrem k radiologické.

\section{Vyšetření a diagnostická kritéria axiální spondyloartritidy}

Rentgenové vyšetření je stále zlatým standardem v diagnostice axiální SpA, ale má své limity. Není vhodné pro záchyt časných stadií axiální SpA a rovněž nezachytí aktivní zánětlivé změny. Vysoce senzitivní vyšetření v diagnostice SpA je magnetická rezonance (MR). Je považována za optimální zobrazovací metodu pro záchyt zánětlivých změn již v počátečních stadiích axiální SpA, umožňuje detailní anatomické zobrazení, detekci kostního edému a známek osteitidy

Pokročilá AS mění držení těla nemocného. Charakteristický je předklon hlavy, vyrovnaná bederní lordóza a mírné pokrčení v kolenou. Při vyšetření je patrná omezená hybnost páteře. Při předklonu sahají konečky prstů rukou u zdravého člověka nejvýše $5 \mathrm{~cm}$ nad podložku, při úklonu k horní hranici kolene. U pacientů s rozvinutým strukturálním postižením axiálního skeletu (Bechtěrevovou chorobou) je tento rozsah nedosažitelný.

Klasifikační kritéria Mezinárodní společnosti pro vyšetření spondyloartritidy (ASAS - Assessment of Spondylo Arthritis International Society) pro axiální SpA definují tuto diagnózu jako:

1) přítomnost sakroileitidy na zobrazovacím vyšetření + alespoň jeden z následujících příznaků, nebo

2) pozitivitu HLA B27 + nejméně dva další příznaky (3):

- zánětlivá bolest v zádech,

- artritida,

- uveitida,

- entezitida,

- daktylitida,

- psoriáza, 


\section{ZAZNĚLO NA 16. KONFERENCI INTERNÍ MEDICÍNA PRO PRAXI}

BOLESTI ZAD U MLADÝCH PACIENTŮ Z POHLEDU REVMATOLOGA

- Crohnova choroba,

- dobrá odpověd' na nesteroidní antirevmatika (NSA),

- pozitivní rodinná anamnéza,

- prítomnost HLA B27 nebo

- lehké zvýšení C-reaktivního proteinu (CRP).

Časné př́iznaky SpA zahrnují také opakující se hydropsy kolenních či jiných kloubů, bolesti pat, zánět Achillovy šlachy a akutní prední uveitidu.

\section{Terapie axiální spondyloartritidy by měla být časná}

Léčba spondyloartritidy se mírně liší u axiální a periferní formy. U obou forem začínáme nesteroidními antiflogistiky (NSA). U periferní formy Ize při progresi choroby podávat sulfasalazin a lokální kortikosteroidy. Vždy je nutná edukace pacienta, cvičení, fyzikální léčba a rehabilitace (4). Pokud onemocnění na tuto terapii nereaguje, Ize uvažovat o nasazení biologické léčby. U axiální formy nejsou konvenční syntetické chorobu modifikující léky typu sulfasalazinu indikovány a po selhání NSA a splnění dalších indikačních kritérií se přistupuje rovnou k biologické léčbě.

Je třeba mít na paměti, že axiální SpA snižuje kvalitu života pacienta (7). Omezená pohyblivost páteře je spojena s řadou omezení, která mohou vést k pracovní neschopnosti (8), ale i omezení psychických a sociálních vazeb (7). U pacientů s axiální SpA byla zjištěna i vyšší mortalita (Obr. 1) $(5,6)$. Axiální SpA se objevuje v rané dospělosti, a příznaky onemocnění tak ovlivňují možnost studia, profesního růstu a sociálního začlenění.

\section{Nutné je včasné vyšetření pacientů se suspektní axiální spondyloartritidou u revmatologa}

Podle průzkumu provedeného v ČR v roce 2008 uplynulo mezi prvními příznaky a diagnózou AS průměrně 9,1 roku. Přitom po 10 letech trvání nemoci bylo $60 \%$ pacientů invalidních a 34\% potřebovalo pomoc druhé osoby (10). Nevratné postižení se tedy objevuje časně (11) a odpověd' na léčbu je lepší při krátkém trvání onemocnění (1). Proto by měl být k revmatologovi včas odeslán každý pacient s chronickou bolestí zad mladší 45 let, u něhož se jedná o zánětlivou bolest

Obr. 1. Zvýšená mortalita pacientů s ankylozující spondylitidou (5)

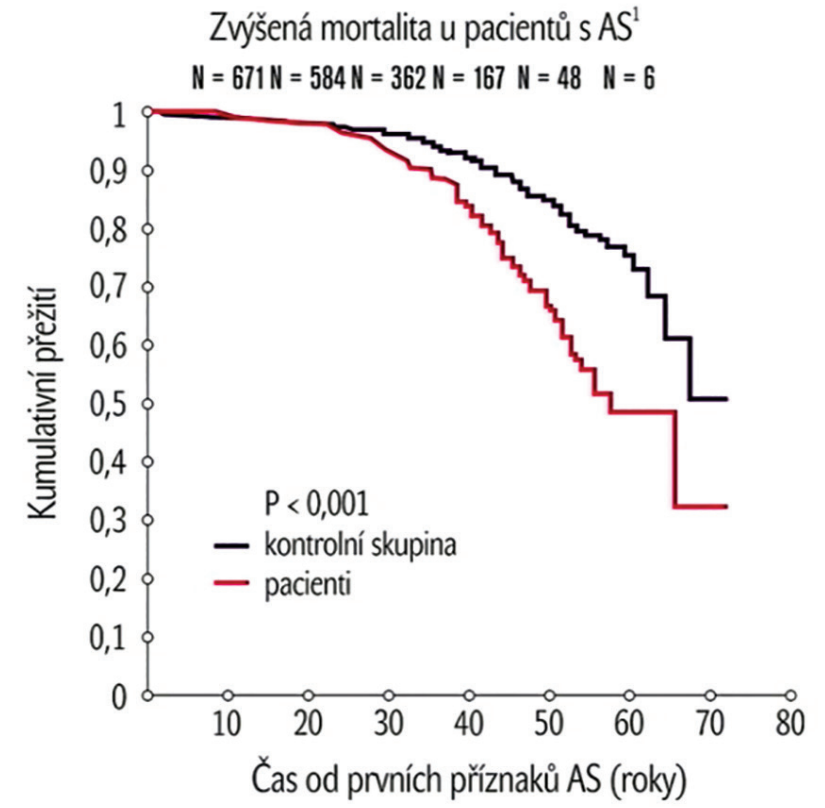

(plíživý začátek, horší v klidu, zmírnění při pohybu) nebo který má sakroileitidu prokázanou pomocí zobrazovací metody nebo pozitivní HLA B27 (Obr. 2) (12, 13).

\section{Kazuistika}

29letý muž byl vyšetřen na revmatologii pro 8 let trvající bolesti zad vyšetřované v ambulancích rưzných specialistů s nekonkluzivním závěrem. Hodnota CRP byla opakovaně < 5 mg/l, antigen HLA B27 byl negativní, negativní byla i rodinná anamnéza. Bolest nereagovala na četná NSA a rentgen páteře a sakroiliakálního skloubení byl opakovaně bez patologického nálezu. Teprve MR ukázala bilaterální sakroileitidu. Pacient tedy splňoval diagnostická kritéria SpA (nález na MR + několikaletá bolest zad zánětlivého charakteru). Vzhledem k absenci odpovědi na NSA byla pacientovi nasazena biologická léčba, se kterou bylo dosaženo úplné remise. Léčbu se tedy podařilo zahájit před invalidizací a pacient je nyní bez obtíźí.

Obr. 2. Suspektni prípady SpA je třeba odeslat k revmatologovi $(12,13)$

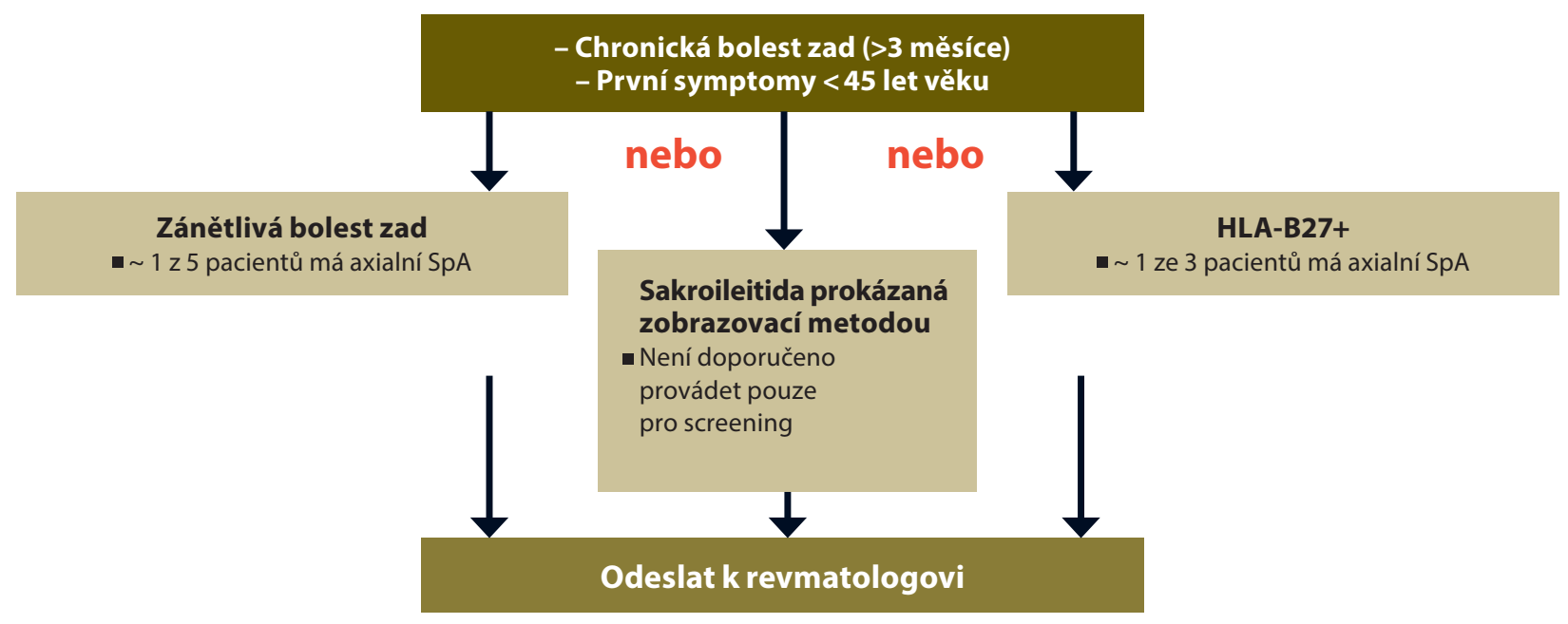




\section{Axiální spondyloartritida ${ }^{5}$}

\section{Spondyloartritidy (SpA)}

Spondyloartritidy představují skupinu zánětlivých revmatických onemocnění, která postihují páteř, sakroiliakální skloubení, ale také periferní klouby a mají i extraartikulární projevy.

Mezi tradiční jednotky patří například ankylozující spondylitida (Bechtěrevova choroba, AS) nebo psoriatická artritida.

Nově zavedený pojem axiální SpA zahrnuje všechny formy postihující převážně osový skelet - páteř a sakroiliakální skloubení, včetně časného onemocnění bez rentgenového průkazu poškození - neradiografická SpA

Axiální SpA nastupuje typicky v mladém věku a vyznačuje se bolestí dolních zad a ztuhlostí páteře s omezením její hybnosti ve všech rovinách.

\section{Axiální SpA}

Zahrnuje formy s axiálním postižením, včetně neradiografické SpA. Postupem času mưže dojít k progresi z neradiografické formy do ankylozující spondylitidy.
Neradiografická axiální SpA

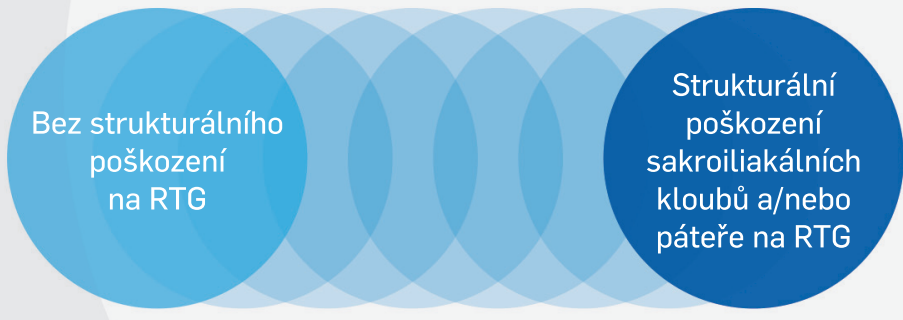

\section{Axiální spondyloartritida}

20-30 let

Ankylozující spondylitida

Typický věk při nástupu nemoci
Ankylozujicí spondylitida

\section{9,1 roku}

Průměrná doba od prvních projevů po stanovení diagnózy v ČR ${ }^{2}$

\section{Jaké jsou nejčastější příznaky axiální SpA ${ }^{5}$}

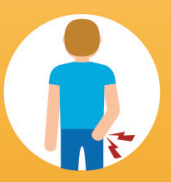

Bolest v oblasti hýždí

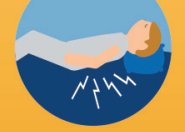

Bolest zad v noci

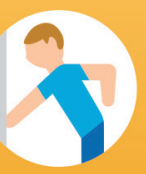

Ranní ztuhlost

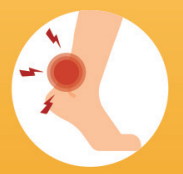

Entezitidy

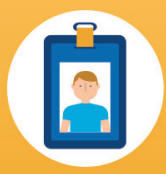

Zhoršená pracovní schopnost

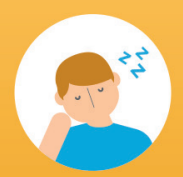

Únava

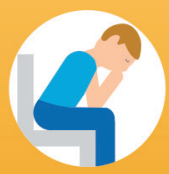

Zhoršená kvalita života

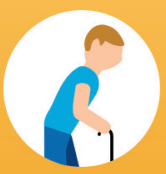

Omezená mobilita

\section{Kdy odeslat pacienta na revmatologii ${ }^{4}$}

\section{Pokud má pacient:}

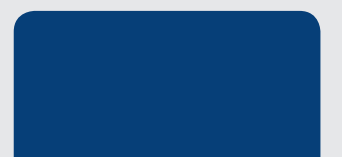

Chronické

bolesti zad

trvající déle než

3 měsíce, které

se objevily ve věku do 45 let.
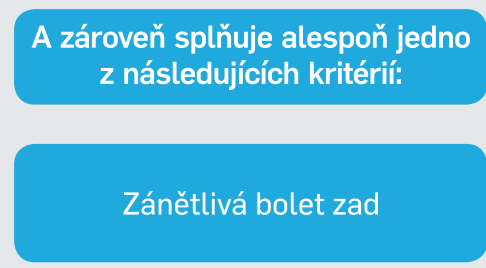

\section{nebo}

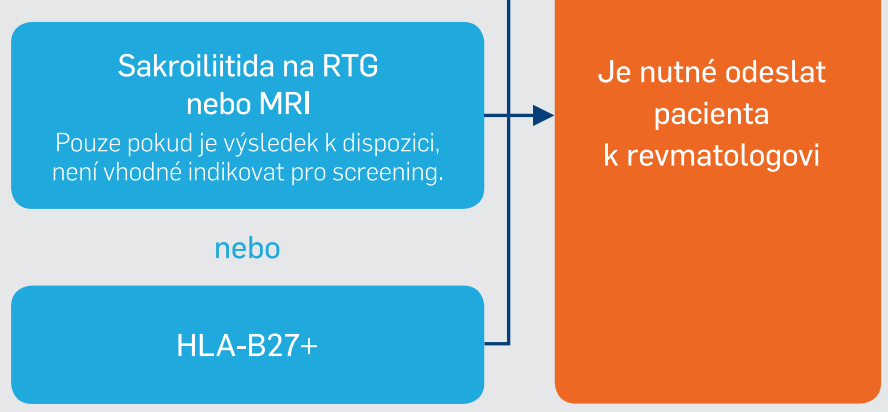

Jak se liší zánětlivá bolest zad od mechanické bolesti zad? ${ }^{4-6}$

Zánětlivá bolest zad

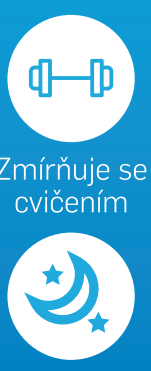

Maximum ve druhé polovině noci (budí ze spánku)

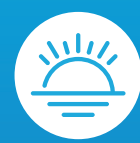

Ranní ztuhlost dolní části zad > 30 min

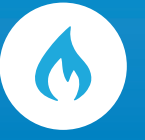

Provázena elevací zánětlivých parametrů

Mechanická bolest zad

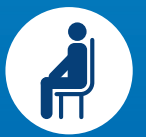

Vázána na pohyb, s úlevou v klidu

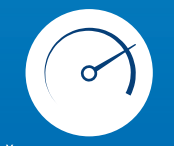

Často prudká, vystřelující

Literatura: 1. Sieper J, Poddubnyy D. Lancet 2017; 390: 73-84. 2. Forejtova, S., et al. (2008). Clin Rheumato/27(8): 1005-1013. 3. Rudweleitet al. Ann Rheum Dis 2011; 70: 25-31. 4. Šenolt L, Mann H, Herle P. Revmatologie. Doporučené

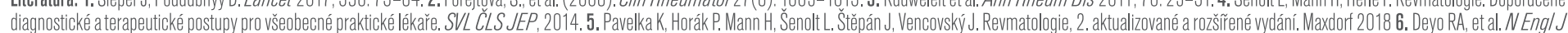
Med. 2001; 344: 363-70. 7. https://www.uptodate.com/contents/axial-spondyloarthritis-ncluding-ankylosing-spondylitis-beyond-the-basics\#!! Datum prístupu leden 2020. 8. https:// nass.co.uk/ [Datum prístupu leden 2020]. 9. Bohn R, et al. Clin Exp Rheumatol. 2018;36:263-74. 10. Strand Vand Singh.JA. Mayo Clin Proc. 2017;92:555-64. 11. RudwaleitM, etal. Ann Rheum Dis. 2006; 65: 1251-2. 12. Kiltz, etal. Rheumatology (Oxford). 2016; 55: 1771-6. 


\section{| ZAZNĚLO NA 16. KONFERENCI INTERNÍ MEDICÍNA PRO PRAX|}

BOLESTI ZAD U MLADÝCH PACIENTO Z POHLEDU REVMATOLOGA

\section{Závěr}

U mladších dospělých pacientů s chronickou bolestí zad je třeba dobře odebrat anamnézu a v diferenciální diagnostice odlišit zánětlivý charakter bolesti. U pacientů se zánětlivým charakterem bolesti zad je vhodné stanovit sedimentaci erytrocytů, krevní obraz, CRP a HLA B27. Žádný z těchto laboratorních testů ale není diagnostický pro spondyloartritidu. V suspektních prípadech je na místě rentgenové vyšetření, které ale může být zejména v počátku onemocnění bez nálezu, nebo vyšetření magnetickou rezonancí. V léčbě je možné nasadit nesteroidní

\section{LITERATURA}

1. Rudwaleit M, Khan MA, Sieper J. The challenge of diagnosis and classification in early ankylosing spondylitis: do we need new criteria? Arthritis Rheum. 2005; 52(4): 1000-1008. 2. Braun J, Baraliakos X. In: Hochberg MC, et al. eds. Rheumatology. 6th ed. 2014: 960-969. 3. Rudwaleit M, van der Heijde D, Landewé R, Listing J, Akkoc N, Brandt J, Braun J, Chou CT, CoIlantes-Estevez E, Dougados M, Huang F, Gu J, Khan MA, Kirazli Y, Maksymowych WP, Mielants H, Sørensen IJ, Ozgocmen S, Roussou E, Valle-Oñate R, Weber U, Wei J, Sieper J. The development of Assessment of SpondyloArthritis international Society classification criteria for axial spondyloarthritis (part II): validation and final selection. Ann Rheum Dis. 2009; 68(6): 777-783. 4. Zochling J, van der Heijde D, Burgos-Vargas R, Collantes E, Davis JC Jr, Dijkmans B, Dougados M, Géher P, Inman RD, Khan MA, Kvien TK, Leirisalo-Repo M, Olivieri I, Pavelka K, Sieper J, Stucki G, Sturrock RD, van der Linden S, Wendling D, Böhm H, van Royen BJ, Braun J; 'ASsessment in AS' international working group; European League Against Rheumatism. ASAS/EULAR recommendations for the management of ankylosing spondylitis. Ann Rheum Dis. 2006; 65(4): 442-452. 5. Bakland G, Gran JT, Nossent JC. Increased mortality in ankylosing spondylitis is related to disease activity. Ann Rheum Dis. 2011; 70(11): 1921-1925.

6. Zochling J, Braun J. Mortality in ankylosing spondylitis. Clin Exp Rheumatol. 2008; 26(5 Suppl 51): $580-584$. antiflogistika. Pacienty mladší 45 let s chronickou zánětlivou bolestí zad, popr. pozitivitou HLA B27 nebo nálezem sakroileitidy na zobrazovacím vyšetření je vhodné odeslat na revmatologické pracoviště. Časné stanovení diagnózy SpA znamená větši šanci na úspěch léčby a snížení rizika vzniku nevratného poškození.

Pripravila MUDr. Zuzana Zafarová Přednáška a článek byly podpořeny společností Novartis

CZ2105313715/05/2021

7. Boonen A, van der Linden SM. The burden of ankylosing spondylitis. J Rheumatol Suppl 2006; 78: 4-11.

8. Franke LC, Ament AJ, van de Laar MA, Boonen A, Severens JL. Cost-of-illness of rheumatoid arthritis and ankylosing spondylitis. Clin Exp Rheumatol. 2009; 27(4 Suppl 55): S118-123. 9. Sieper J, Braun J, Rudwaleit M, Boonen A, Zink A. Ankylosing spondylitis: an overview. Ann Rheum Dis. 2002; 61 Suppl 3(Suppl 3): iii8-18.

10. Forejtová S, Mann H, Stolfa J, Vedral K, Fenclová I, Némethová D, Pavelka K. Factors influencing health status and disability of patients with ankylosing spondylitis in the Czech Republic. Clin Rheumatol. 2008; 27(8): 1005-1013.

11. Keat A, Gaffney K, Marzo-Ortega H, Cornell T, Mackay K, Skerrett J, Van Rossen L, Wordsworth BP. Improving the treatment of ankylosing spondylitis in the UK. Rheumatology (Oxford). 2011; 50(11): 1936-1939.

12. Sieper J, Rudwaleit M. Early referral recommendations for ankylosing spondylitis (including pre-radiographic and radiographic forms) in primary care. Ann Rheum Dis. 2005; 64(5): 659-663.

13. Šenolt I, Mann H, Herle P a výbor ŘS ČLS JEP. Doporučené diagnostické a terapeutické postupy pro všeobecné praktické lékaře. Revmatologie, SVL ČLS JEP 2014. 